\title{
PROSES SENGKETA ANTROPOLOGI HUKUM \\ DALAM PERKEMBANGANNYA
}

\author{
REKY ARDI \\ Email : rekyardi123@gmail.com \\ No. BP : 2110003600120 \\ UNIVERSITAS EKASAAKTI PADANG
}

\section{A. Pendahuluan}

Indonesia adalah negara kepulauan dengan aneka ragam suku bangsa dan budaya, juga memiliki keanekaragaman hukum adat. Keanekaragaman hukum tersebut pada akhirnya melahirkan perbedaan dari masing-masing daerah dalam hal penyelesaian konflik. Masingmasing daerah mempunyai mekanisme penyelesaian konflik sendiri-sendiri. Juga perlu dipahami bahwa Indonesia dengan mayoritas penduduk muslim terbesar. Perkembangan yang terjadi dalam kehidupan manusia selalu berhadapan dengan konflik yang mewarnai kehidupan. Konsep antropologi dalam pandangan hukum sebenarnya telah lama dibicarakan oleh para pakar, khususnya pada zaman kolonialisme, hal ini tentunya dengan tujuan tertentu yang mereka buat. Namun metode selalu menarik untuk ditelusuri kembali.

Tulisan ini berupaya untuk mendalami kajian antropologi hukum dalam penyelesaian sengketa. Pemahaman dengan Antropologi sebenarnya telah banyak dibicarakan oleh para ahli antropologi, sehingga ketika membicarakan antropologi maka akan banyak literatur yang menjelaskannya. Dalam kamus Bahasa Indonesia mengartikan dengan ilmu tentang manusia, khususnya tentang asal usul, perkembangan, adat istiadat, dan kepercayaannya pada masa lampau. Model Antropologi Hukum yaitu holistik dengan latar belakang budaya hukum dari masyarakat setempat ini memberikan gambaran bahwa hukum tidak hanya dilihat pada 
persoalan berundangan (normative) atau hukum adat melainkan ada peran budaya peran tersebut dapat dilihat dari cara menyelesaikan masalah dengan budaya yang tertanam.

Hukum tidak bisa melihat nilai budaya tersebut tanpa mempelajari antropologi hukum, sebab pendekatan dari penyelesaian masalah ini memerlukan pemahaman latar belakang budaya setempat. Pada hakekatnya proses sengketa antropologi hukum adalah suatu rangkaian proses yang dilakukan untuk mendapatkan penyelesaian suatu sengketa Muhammad Ilham, dan M. Taufiq (2021). Sengketa merupakan permasalahan peradilan yang harus diselesaikan. Menurut R Subekti dan R Tjitrosedibio dalam Muhammad Ilham, dan M. Taufiq (2021), peradilan merupakan segala sesuatu yang berkaitan dengan tugas negara untuk ,memegakan hukum dan keadilan. Umumnya seseorang mendapat keadilan melalui pengadilan yang mendapat naungan dari Mahkamah Agung. Ini telah diatur dalam Undang - Undang Republik Indonesia Nomor 2 Tahun 1986 tentang peradilan umum bahwa pengadilan adalah salah satu pelaksana kekuasaan kehakiman bagi rakyat yang mencari keadilan tetapi itu juga harus mewujudkan kepastian hukum sebagai nilai yang terkandung dalam peraturan hokum, dalam Muhammad Ilham, dan M. Taufiq (2021).

Konsep antropologi dalam pandangan hukum sebenarnya telah lama dibicarakan oleh para pakar, khususnya pada zaman kolonialisme, hal ini tentunya dengan tujuan tertentu yang mereka buat. Namun metode selalu menarik untuk ditelusuri kembali. Tulisan ini berupaya untuk mendalami kajian antropologi Hukum dalam penyelesaian sengketa. Atau bisa disebut juga dengan proses sengketa antropologi hukum dalam perkembangannya. 


\section{B. Pembahasan}

Penyelesaian sengketa bukan hanya sekedar membuktikan yang benar dan yang salah, akan tetapi tujuan utama dari keberadaan hukum adalah menciptakan ketertiban masyarakat. Banyak bisa kita jumpai dimasyarakan berbagai cara dalam penyelesaian sengketa, namun yang mesti dihindari adalah adanya upaya sengketa dengan jalan pertikaian yang dapat merugikan pihak lain.

Menurut T.O. Ihromi dalam Muhammad Ilham, dan M. Taufiq (2021) bahwa antropologi hukum merupakan cabang dari antropologi budaya yang hendak memahami bagaimana masyarakat mempertahankan nilai-nilai yang dijunjung tinggi melalui proses pengendalian sosial yang salah satunya berbentuk hukum. Hal ini diperkuat juga oleh Sir Henry maine yang menyatakan bahwa antropologi hukum sebagai bagian dari budaya. Pendapat lain juga mengatakan bahwa Antropologi hukum mempelajari hukum dari konteks kultur masyarakat tertentu, baik pada masyarakat modern, maupun masyarakat sederhana. Dengan kata lain, Antropologi Hukum adalah Antropologi yang mempelajari Hukum sebagai salah satu aspek dari kebudayaan. Soerjono Soekanto berpendapat bahwa semua masyarakat mempunyai aturan-aturan yang mengatur perilaku manusia; aturan - aturan tertentu bersifat hanya sebagai patokan preferensi, namun yang lain dianggap sebagai patokan perilaku yang pantas dilakukan. Apabila suatu aturan itu dilanggar, maka masyarakatnya lazimnya telah sepakat untuk menerapkan upaya-upaya penghukuman tertentu dan hal ini menjadi pusat perhatian para antropolog hukum.

\section{a. Sengketa dalam Lingkup Teori}

Sengketa dalam kamus bahasa Indonesia dimaknai dengan bentrokan, cedera, friksi, kelahi, konflik, konfrontasi, perbalahan, pergesekan, perselisihan, pertengkaran, 
pertentangan, pertikaian. Menurut Nurnaningsih Amriani (2018), sengketa merupakan perselisihan yang terjadi antara para pihak dalam perjanjian karena adanya wan prestasi yang dilakukan oleh salah satu pihak dalam perjanjian tersebut Muhammad Ilham, dan M. Taufiq (2021). Sedangkan menurut Takdir Rahmadi (2011), sengketa adalah situasi dan kondisi dimana orang-orang saling mengalami perselisihan yang bersifat factual maupun perselisihan menurut persepsi mereka saja. Sengketa adalah kondisi dimana ada pihak yang merasa dirugikano leh pihak lain, yang kemudian pihak tersebut menyampaikan ketidakpuasan tersebut kepada pihak kedua. Apabila suatu kondisi menunjukkan perbedaan pendapat, maka terjadilah apa yang dinamakan sengketa tersebut.

Dalam konteks hukum khususnya hukum kontrak, yang dimaksud dengan sengketa adalah perselisihan yang terjadi antara para pihak karena adanya pelanggaran terhadap kesepakatan yang telah dituangkan dalam suatu kontrak, baik sebagian maupun keseluruhan. Sehingga dengan kata lain telah terjadi wan prestasi oleh pihak-pihak atau salah satu pihak, karena tidak dipenuhinya kewajiban yang harus dilakukan atau dipenuhi namun kurang atau berlebihan yang akhirnya mengakibatkan pihak satunya dirugikan. Sengketa yang timbul antara para pihak harus diselesaikan agar tidak menimbulkan perselisihan yang berkepanjangan dan agar memberikan keadilan dan kepastian hukum bagi para pihak Muhammad Ilham, dan M. Taufiq (2021). Secara garis besar bentuk penyelesaian sengketa dapat dilakukan melalui dua cara yaitu jalur litigasi maupun jalur non-litigasi. Ada juga dalam sengketa antara konsumen dan pelaku rentenir yang cukup banyak timbul persengketaan. 


\section{b. Sebab terjadinya Sengketa}

Dalam beberapa literatur dijelaskan bahwa ada beberapa sebab terjadinya sengketa didalam masyarakat, yakni :

\section{Teori Hubungan masyarakat}

Teori hubungan masyarakat, menitikberatkan adanya ketidakpercayaan dan rivalisasi kelompok dalam masyarakat. Para penganut teori ini memberikan solusi - solusi terhadap konflik-konflik yang timbul dengan cara peningkatan komunikasi dan saling pengertian antara kelompok-kelompok yang mengalami konflik, serta pengembangan toleransi agar masyarakat lebih bisa saling menerima keberagaman dalam masyarakat.

\section{Teori Negosiasi prinsip}

Teori negosiasi prinsip menjelaskan bahwa konflik terjadi karena adanya perbedaan-perbedaan diantara para pihak. Para penganjur teori ini berpendapat bahwa agar sebuah konflik dapat diselesaikan, maka pelaku harus mampu memisahkan perasaan pribadinya dengan masalah-masalah dan mampu melakukan negosiasi berdasarkan kepentingan dan bukan pada posisi yang sudah tetap.

\section{Teori identitas}

Teori ini menjelaskan bahwa konflik terjadi karena sekelompok orang merasa identitasnya terancam oleh pihak lain. Penganut teori identitas mengusulkan penyelesaian konflik karena identitas yang terancam dilakukan melalui fasilitasi lokakarya dan dialog antara wakil-wakil kelompok yang mengalami konflik dengan tujuan mengidentifikasikan ancaman-ancaman dan kekhawatiran yang mereka rasakan serta membangun empati dan rekonsiliasi. Tujuan akhirnya adalah pencapaian kesepakatan bersama yang mengakui identitas pokok semua pihak. 


\section{Teori kesalahpahaman antar budaya}

Teori kesalahpahaman antar budaya menjelaskan bahwa konflik terjadi karena ketidakcocokan dalam berkomunikasi diantara orang - orang dari latar belakang budaya yang berbeda. Untuk itu, diperlukan dialog antara orang-orang yang mengalami konflik guna mengenal dan memahami budaya masyarakat lainnya, mengurangi stereotip yang mereka miliki terhadap pihak lain.

\section{Teori transformasi}

Teori ini menjelaskan bahwa konflik dapat terjadi karena adanya masalah - masalah ketidaksetaraan dan ketidakadilan serta kesenjangan yang terwujud dalam berbagai aspek kehidupan masyarakat baik sosial, ekonomi maupun politik. Penganut teori ini berpendapat bahwa penyelesaian konflik dapat dilakukan melalui beberapa upaya seperti perubahan struktur dan kerangka kerja yang menyebabkan ketidaksetaraan, peningkatan hubungan, dan sikap jangka panjang para pihak yang mengalami konflik, serta pengembangan prosesproses dan sistem untuk mewujudkan pemberdayaan, keadilan, rekonsiliasi dan pengakuan keberadaan masing - masing.

\section{Teori kebutuhan atau kepentingan manusia}

Pada intinya, teori ini mengungkapkan bahwa konflik dapat terjadi karena kebutuhan atau kepentingan manusia tidak dapat terpenuhi atau terhalangi atau merasa dihalangi oleh orang atau pihak lain. Kebutuhan dan kepentingan manusia dapat dibedakan menjadi tiga jenis yaitu substantif, prosedural, dan psikologis. Kepentingan substantif (substantive) berkaitan dengan kebutuhan manusia yang yang berhubungan dengan kebendaan seperti uang, sandang, pangan, papan/rumah, dan kekayaan. Kepentingan prosedural (procedural) berkaitan dengan tata dalam pergaulan masyarakat, sedangkan 
kepentingan psikologis (psychological) berhubungan dengan non-materiil atau bukan kebendaan seperti penghargaan dan empati.

Dalam perspektif Antropologi Hukum, konflik yang yang terjadi dalam masyarakat paling tidak dapat dikategorisasi menjadi 3 macam Muhammad Ilham, dan M. Taufiq (2021)., yaitu:

a) Konflik kepentingan (conflict of interests)

b) Konflik nilai-nilai (conflict of values)

c) Konflik norma (conflict of norms).

\section{c. Penyelesaian Sengketa}

Dalam beberapa literatur ditemukan beberapa cara penyelesaian sengketa yang dapat ditempuh dalam mencari keadilan. Menurut Pruitt dan Rubin dalam Muhammad Ilham, dan M. Taufiq (2021), terdapat lima cara penyelesaian sengketa, yaitu :

1. Contending (bertanding), yaitu mencoba menerapkan suatu solusi yang lebih disukai oleh salah satu pihak atas pihak yang lainnya.

2. Yielding (mengalah), yaitu menurunkan aspirasi sendiri dan bersedia menerima kekurangan dari yang sebetulnya diinginkan.

3. Problem solving (pemecahan masalah), yaitu mencari alternatif yang memuaskan dari kedua belah pihak.

4. With drawing (menarik diri), yaitu memilih meninggalkan situasi sengketa, baik secara fisik maupun psikologis. 
5. In action (diam), yaitu tidak melakukan apa-apa, Lebih lanjut lagi menurut Nader dan Todd Jr terdapat tujuh cara penyelesaian sengketa dalam masyarakat, Muhammad Ilham, dan M. Taufiq (2021) yaitu :

- Lumpingit (membiarkan saja), oleh pihak yang merasakan perlakuan tidak adil, gagal dalam mengupayakan tuntutannya. Dia mengambil keputusan untuk mengabaikan saja masalahnya atau isuisu yang menimbulkan tuntutannya dan dia meneruskan hubungan -hubungannya dengan pihak yang dirasakan merugikannya.

- Avoidance (mengelak), yaitu pihak yang merasa dirugikan, memilih untuk mengurangi hubungan-hubungan dengan pihak yang merugikannya atau untuk sama sekali menghentikan hubungan tersebut, misalkan dalam hubungan bisnis hal serupa bisa saja terjadi. Dengan mengelak, maka masalah yang menimbulkan keluhan dielakkan saja.

- Coercion (paksaan), pihak yang satu memaksakan pemecahan kepada pihak lain, ini bersifat unilateral. Tindakan yang bersifat memaksakan atau ancaman untuk menggunakan kekerasan, pada umumnya mengurangi kemungkinan penyelesaian secara damai.

- Negotiation (perundingan), kedua belah pihak yang berhadapan merupakan para pengambil keputusan. Pemecahan masalah yang dihadapi dilakukan oleh mereka berdua, mereka sepakat tanpa adanya pihak yang ketiga yang mencampurinya. Kedua belah pihak berupaya untuk saling menyakinkan, jadi mereka membuat aturan mereka sendiri dan tidak memecahkannya dengan bertitik tolak dari aturanaturan yang ada. 
- Mediation (mediasi), pihak ketiga yang membantu kedua belah pihak yang berselisih pendapat untuk menemukan kesepakatan. Pihak ketiga ini dapat ditentukan oleh kedua belah pihak yang bersengketa, atau ditunjukkan oleh pihak yang berwenang untuk itu.

- Arbitration (Arbitrase), yaitu dua belah pihak yang bersengketa sepakat untuk meminta perantara kepada pihak ketiga, arbitrator dan sejak semula telah setuju bahwa mereka akan menerima keputusan dari arbitrator tersebut.

- Adjudication (peradilan), yaitu pihak ketiga yang mempunyai wewenang untuk mencampuri pemecahan masalah, lepas dari keinginan para pihak yang bersengketa. Pihak ketiga itu juga berhak membuat keputusan dan menegakkan keputusan itu artinya pihak ketiga berupaya bahwa keputusan itu dilaksanakan. Dalam teori lain dijelaskan bahwa ada beberapa model penangan sengketa.

Model-model penanganan sengketa sangat bervariasi tetapi dapat diklasifikasikan ke dalam suatu prosuder yang bersifat umum Beberapa berupa penanganan dyadic (dua arah), seperti negosiasi yang mencakup dua pihak saja, yang mengembangkan aturanaturannya sendiri dan mencapai kesepakatan melalui kompromi. Namun banyak bentuk dari penyelesaian sengketa adalah triadic dan melibatkan pihak-pihak ketiga. Peran dan kekuasaan dari pihak ketiga itu tergantung pada struktur dari proses resolusinya. Mediasi merupakan proses yang bersifat mendamaikan (conciliatory), pihak ketigamembantu dua pihak yang bersengketa mencapai suatu penyelesaian tetapi tidak memiliki otoritas untuk memaksa salah satu pihak. Dalam arbitrasi, pihak-pihak yang bersengketa sepakat pada tingkat yang lebih tinggi, untuk menerima keputusan pihak ketiga sebagai hal yang mengikat. Dalam ajudikasi, negara memberi kuasa 
(kepada )hakim untuk membuat keputusan yang mengikat tanpa harus mempertimbangkan persetujuan para pihak yang bersengketa.

\section{d. Kajian Antropologi Hukum dalam Penyelesaian Sengketa}

Pemahaman dengan Antropologi sebenarnya telah banyak dibicarakan oleh para ahli antropologi, sehingga ketika membicarakan antropologi maka akan banyak literatur yang menjelaskannya. Dalam kamus Bahasa Indonesia mengartikan dengan ilmu tentang manusia, khususnya tentang asal-usul, perkembangan, adatistiadat, dan kepercayaannya pada masa lampau. Antropologi dikaji sebagai satu disiplin ilmu dalam mengkaji manusia secara fisik dan aspek tingkah laku kebudayaannya, ilmu ini dikaji untuk mengkaji aktivitas manusia. Para ahli antropologi tampaknya lebih mengkaji secara empirik dari masyarakat dan kebudayaannya. sehingga bagi seorang antropologi maka istilah - kebudayaan umumnya mencakup cara berpikir dan cara berlaku yang telah merupakan ciri khas suatu bangsa atau masyarakat tertentu.

Membahas tentang hukum bahwa hukum sangat erat kaitannya dengan kebudayaan, sehingga hukum itu sendiri produk kebudayaan. Dalam studi hukum dikenal struktur hukum, substansi hukum, dan budaya hukum. Hukum diciptakan memiliki karakteristik yang berbeda-beda dari satu daerah ke daerah lainnya sesuai dengan kebudayaan setempat. Artinya, kebudayaan membentuk hukum. Menurut Prof. Tjip, dalam Takdir Rahmadi (2011), hukum itu bukanlah skema yang final, tetapi terus bergerak sesuai dengan dinamika dan perkembangan zaman umat manusia. Artinya, hukum akan terus berubah sesuai dengan perkembangan zaman dan dinamika manusia ini terlahir dalam proses kebudayaan yang berbeda. 
Dalam perkembangan antropologi, masalah hukum sebenarnya juga sudah pernah ditelaah, walaupun di dalam suatu kerangka kebudayaan yang serba luas. Sarjana - sarjana antropologi seperti Barton, Radcliffe-Brown, Malinowski dan lainnya, pernah memusatkan perhatian pada hukum sebagai suatu gejala social budaya.

\section{Penutup}

Dalam perspektif antropologi hukum, fenomena konflik mempunyai makna ganda yaitu makna negatif dan makna positif. Makna negatif, konflik menimbulkan disintegrasi suatu kehidupan sosial dan melemahkan kohesi sosial atau menimbulkan kerusakan suatu sistem hubungan sosial dalam masyarakat. Makna positif, konflik dapat mempertahankan integrasi sosial, memperkokoh ikatan sosial, memberi kontribusi untuk mengembalikan keseimbangan hubungan sosial antar individu atau kelompok. Makna positif akan terwujud jika pihak-pihak yang terlibat konflik secara bersama-sama dapat mengelola, mengendalikan, dan menyelesaikan konflik yang dihadapi secara dewasa, bijak, damai, dengan atau tanpa mengundang kehadiran pihak ketiga.

Aspek antropologi dalam lingkup penyelesaian sengketa baik secara litigasi maupun non litigasi sangat bermanfaat untuk dikaji serta dipelajari oleh para penegak hukum, sebab secara umum bahwa hukum secara nasional tidak terbentuk begitu saja tanpa ada pengaruh dari perspektif masyarakat. Terlebih lagi bagi wilayah indonesia yang tidak lepas dari corak adat yang masih sangat kental berlaku diwilayah masing-masing. Dengan adanya kolaborasi ini tentu akan menambah serta membuat aspek keadilan terwujud. 


\section{DAFTAR PUSTAKA}

Darmini Roza dan Laurensius Arliman S, Peran Pemerintah Daerah Di Dalam Melindungi Hak Anak Di Indonesia, Masalah-Masalah Hukum, Volume 47, Nomor 1, 2018. https://doi.org/10.14710/mmh.47.1.2018.10-21

Laurensius Arliman S, Peranan Metodologi Penelitian Hukum di Dalam Perkembangan Ilmu Hukum di Indonesia, Soumatera Law Review, Volume 1, Nomor 1, 201. http://doi.org/10.22216/soumlaw.v1i1.3346.

Laurensius Arliman S, Peran Badan Permusyawaratan Desa di Dalam Pembangunan Desa dan Pengawasan Keuangan Desa, Padjadjaran Journal of Law, Volume 4, Nomor 3, 2017. https://doi.org/10.15408/jch.v4i2.3433.

Laurensius Arliman S, Penanaman Modal Asing Di Sumatera Barat Berdasarkan Undang- Undang Nomor 25 Tahun 2007 Tentang Penanaman Modal, Supremasi Hukum, Volume 1, Nomor 1, 2018. http://dx.doi.org/10.36441/hukum.v1i01.102 .

Laurensius Arliman S, Memperkuat Kearifan Lokal Untuk Menangkal Intoleransi UmatBeragama Di Indonesia, Ensiklopedia of Journal, Volume 1, Nomor 1, 2018, https://doi.org/10.33559/eoj.v1i1.18.

Laurensius Arliman S, Perkawinan Antar Negara Di Indonesia Berdasarkan Hukum Perdata Internasional, Kertha Patrika, Volume 39, Nomor 3, 2017,https://doi.org/10.24843/KP.2017.v39.i03.p03.

Laurensius Arliman S, Partisipasi Masyarakat Di Dalam Pengelolaan Uang Desa PascaUndang-Undang Nomor 6 Tahun 2014 Tentang Desa, Jurnal Arena Hukum, Volume 12, Nomor 2, 2019, https://doi.org/10.21776/ub.arenahukum.2019.01202.5.

Laurensius Arliman S, Mewujudkan Penegakan Hukum Yang Baik Di Negara Hukum Indonesia, Dialogica Jurnalica, Volume 11, Nomor 1, 2019, https://doi.org/10.28932/di.v11i1.1831.

Laurensius Arliman S, Mediasi Melalui Pendekatan Mufakat Sebagai Lembaga Alternatif Penyelesaian Sengketa Untuk Mendukung Pembangunan Ekonomi Nasional, UIR Law Review, Volume 2, Nomor 2, 2018, https://doi.org/10.25299/uirlrev.2018.vol2(02).1587

Laurensius Arliman S, Peranan Filsafat Hukum Dalam Perlindungan Hak Anak Yang Berkelanjutan Sebagai Bagian Dari Hak Asasi Manusia, Doctrinal, Volume 1, Nomor 2,2016.

Laurensius Arliman S, Ni Putu Eka Dewi, Protection of Children and Women's Rights in Indonesiathrough International Regulation Ratification, Journal of Innovation, Creativity and Change Volume 15, Nomor 6, 2021.

Laurensius Arliman S, Gagalnya Perlindungan Anak Sebagai Salah Satu Bagian Dari Hak Asasi Manusia Oleh Orang Tua Ditinjau Dari Mazhab Utilitarianisme, Jurnal Yuridis, Volume 3, Nomor 2, 2016, http://dx.doi.org/10.35586/.v3i2.180.

Laurensius Arliman S, Tantangan Pendidikan Kewarganegaraan Pada Revolusi 4.0, Jurnal Ensiklopedia Sosial Review, Volume 2, Nomor 3, 2020.. 